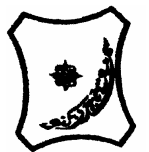

Bayero Journal of Pure and Applied Sciences, 9(2): 251 - 257

Received: February, 2016

Accepted: August, 2016

ISSN $2006-6996$

\title{
EFFECT OF IRRIGATION ON HEAVY METALS CONTENT OF WASTEWATER IRRIGATED FLUVISOLS ALONG RIVER TATSEWARKI, KANO, NIGERIA
}

\author{
Omar, G. ${ }^{*}$ and Pantami, S. A. \\ Department of Soil Science, Faculty of Agriculture, Bayero University, Kano, Nigeria, \\ * Corresponding author; GSM: 08069593170; E-mail: omargarba1@yahoo.com
}

\begin{abstract}
There is an urgent need to educate farmers on the dangers of the presence of heavy metals in soils as well as the quality of irrigation water especially if it comes from tanning industries for increased crop production. Accordingly, soil and irrigation wastewater study was conducted to assess the concentrations of heavy metals in wastewater irrigated Fluvisols and in the irrigation wastewater itself as well as the relationship between the two. Composite surface soil and water samples including controls were collected and analyzed using standard methods. Analytical results were compared with the controls, the EU and FAO standards. Results indicated that the concentrations of $\mathrm{Cu}$ (30.556 to $\left.41.667 \mathrm{mgkg}^{-1}\right), C d\left(10.269\right.$ to18.687 $\left.\mathrm{mgkg}^{-1}\right), \mathrm{Zn}\left(18.687\right.$ to $\left.26.010 \mathrm{mgkg}^{-1}\right), \mathrm{Cr}$ (8.848 to $12.14 \mathrm{mgkg}^{-1}$ ) and Pb (3.953 to $4.787 \mathrm{mgkg}^{-1}$ ) in the soil were non-toxic across the river sections. Results also indicated that the irrigation water contained toxic levels of $\mathrm{Cu}$ (0.85 to1.25 $\left.\mathrm{mgr}^{1}\right), \mathrm{Cd}\left(0.36\right.$ to $\left.0.72 \mathrm{mgr}^{1}\right)$ and $\mathrm{Cr}\left(0.47\right.$ to $\left.0.67 \mathrm{mgr}^{1}\right)$ and is therefore considered unsafe for use. However, it did not contain toxic levels of Zn $\left(0.581 .06 \mathrm{mgr}^{1}\right)$ and Pb $\left(0.22\right.$ to $\left.0.25 \mathrm{mgr}^{1}\right)$ and it is considered safe for use accordingly. Results also revealed that the irrigation water was responsible for the accumulation of $\mathrm{Cr}(r=0.019), \mathrm{Cu}(r=0.151), \mathrm{Cd}(r=0.190)$ and $\mathrm{Pb}(r=$ $0.202)$ in the irrigated soils but not $\mathrm{Zn}(r=-0.214)$. It is recommended that periodic appraisal of the soils should be embarked upon so as to monitor the toxicity level of the soil to keep it within the present non-toxic level. It is also recommended that the wastewater should be remediated to minimize and control the heavy metal contamination through phytoremediation. These measures are expected to enhance increased and sustainable crop production in the study area.
\end{abstract}

Key words: Fluvisols, Heavy metals, Irrigation, Wastewater.

\section{INTRODUCTION}

The term heavy metal refers to any metallic chemical element that has a relatively high density and is toxic or poisonous even at low concentrations (Lentech, 2012). Heavy metals occur naturally and they come from many different sources like, mining industries, burning of fossil fuels like coal, burning garbage or tobacco, forest fires, textile and tanneries (C.R.D., 2004). Heavy metals are currently of much environmental concern being harmful to humans, animals and are susceptible to bio-accumulation in the food chain. Heavy metals are known to be nonbiodegradable, and they persist for long duration in aquatic as well as terrestrial environment, which also served as a major contributor to heavy metals contamination in top soil (Kelly et al., 1996). Heavy metals such as $\mathrm{Pb}, \mathrm{As}, \mathrm{Hg}, \mathrm{Cd}$ and $\mathrm{Al}$ are among the most dangerous toxins in our ecosystem. They might be transported from soil to ground waters which may be used for irrigation purposes and may be taken up by plants including agricultural crops. Therefore the knowledge of metal - soils and plant interaction is very important for the safety of the environment. Heavy metals pollution of agricultural soils is one of the most land severe ecological problems faced worldwide (Shukry, 2001). The direct discharge of effluents from industries into bodies of water has become a growing environmental problem (Akan et al., 2007). Most of these waste waters are extremely complex mixtures containing organic and inorganic compounds (Fu et al., 1994). Farmers are ignorant about the hidden toxicity of heavily polluted discharges and their subsequent negative impact as a result of using contaminated water for their crops (Nath et al., 2005). High concentrations of heavy metals in irrigation water can result in death of crops, interfere with uptakes of other essential nutrients or for objectionable deposits on fruits and render edible portion of plants toxic to human and grazing animals, (Aikman,1983). Presence of pollutants in water alters different physico-chemical parameters from their normal prescribed levels (Mishra and Pandey, 2005). Tanning industrial wastes rank among the most polluting of all industrial wastes and are a serious threat when they pollute stream and fresh water bodies (Javaid, 2000). Consequently, the tanning industry is a potentially pollution intensive industry. Some heavy metals contained in these effluents (either in free form in the effluents or adsorbed in the suspended solid) from the industries have been found to be carcinogenic while other chemicals equally present are poisonous depending on the dose and exposure duration (Kupechella and Hyland, 1986). 
BAJOPAS Volume 9 Number 2 December, 2016

It has been reported that only about $20 \%$ of the large number of chemicals used in the tanning process is absorbed by leather, the rest is released as waste (Kupechella and Hyland, 1986).

A number of studies are conducted in order to draw the attention of farmers to heavy metals accumulation in soils and plants (Shallari et al., 1998, Jamali et al., 2009). Micó et al.,(2006) reported mean values (mg $\mathrm{kg}^{-1}$ ) of heavy metals at the Segura River Valley, Alicante, Spain, as Cd, 0.38; Co, 7.9; $\mathrm{Cr}$, 28.3; Cu, 21.6; $\mathrm{Fe}, 15,274 ; \mathrm{Mn}, 320 ; \mathrm{Ni}, 23.7 ; \mathrm{Pb}, 19.6$; and $\mathrm{Zn}$, 57.8. These values followed the sequence: $\mathrm{Fe}>\mathrm{Mn}>$ $\mathrm{Zn}>\mathrm{Cr}>\mathrm{Ni}>\mathrm{Cu}>\mathrm{Pb}>\mathrm{Co}>\mathrm{Cd}$. Omar (2010) reported $\mathrm{Zn}$ and $\mathrm{Cu}$ range of 2.99 to 4.43 and 0.75 to $1.42 \mathrm{mg} / \mathrm{kg}$, respectively for Fluvisols in southwestern Bauchi State, Nigeria. These levels were considered to be adequate for crop production. Fluvisols receive deposits of different materials including heavy metals with each flooding especially when they are irrigated with wastewater. Their evaluation for these metals is of utmost importance. Kobierski (2015) reported contamination of Fluvisols with heavy metals in the surface layer at Vistula River floodplain in the Chełmiński and Nadwiślański areas in Poland. Comprehensive reports on heavy metals contents of soils in Kano urban agricultural lands have been reported by Dawaki et al., 2013; Mashi and Alhassan, 2007.

With about nine (9) tanning industries in Sharada Industrial Area (FME, 2001), where this study was carried out, coupled with the continuous use of the discharged tannery effluents into surrounding rivers from the industries, including the river under study, heavy metals are bound to be deposited in the soils which may affect crop production. This is further aggravated by the rapid expansion of Kano city leading to urban and peri-urban agriculture which most often necessitates the use of contaminated wastewater for irrigation purposes. It is imperative to study the levels of these heavy metals in both soils and irrigation water along the Tatsewarki River so as to assess their level of contamination as well as the effect of the irrigation water on the soils for increased and sustainable crop production in the study area. The study is an attempt in this direction.

\section{MATERIALS AND METHODS \\ Description of Study Area}

The study was carried out on Fluvisols along River Tatsewarki of Kano, Nigeria. The study area is located on latitudes $11^{\circ} 53^{\prime \prime} 20^{\prime \prime} \mathrm{N}$ to $11^{\circ} 56^{\prime \prime} 40^{\prime \prime} \mathrm{N}$ and longitudes $8^{\circ} 30^{\prime} 0^{\prime \prime} \mathrm{E}$ to $8^{\circ} 33^{\prime \prime} 20^{\prime \prime} \mathrm{E}$ (Figures 1 and 2). River Tatsewarki is one of the main drains in the southern part of Kano draining into river Challawa and conveys it to River Challawa (Bichi and Anyata,1999). The area has an average elevation of $412 \mathrm{~m}$ above sea level, and the total length of this river has been estimated to be about $18.6 \mathrm{~km}$; covering a longitudinal distance of about $12.3 \mathrm{~km}$.

The study area is located within the savannah agroecological zone of West Africa. The climate is classified as tropical savannah. The area falls within the northern part of the Kano region with four distinct seasons namely; the dry and cool season, the dry and hot season, the wet and warm season (rainy season), and the dry and warm season as described by Olofin (1987). The mean annual rainfall is about $600 \mathrm{~mm}$ to $750 \mathrm{~mm}$ received between May and October in a normal year. The mean annual temperature ranges from $23{ }^{\circ} \mathrm{C}$ to about $26{ }^{\circ} \mathrm{C}$ in the coolest season and $27{ }^{\circ} \mathrm{C}$ to $33^{\circ} \mathrm{C}$ in the hottest season.

The dominant land use in the area includes residential, commercial, industrial, urban and periurban agriculture. The major crops grown under rain fed agriculture include maize, sorghum and millet. Some areas are also densely populated with tree crops such as mango and guava.

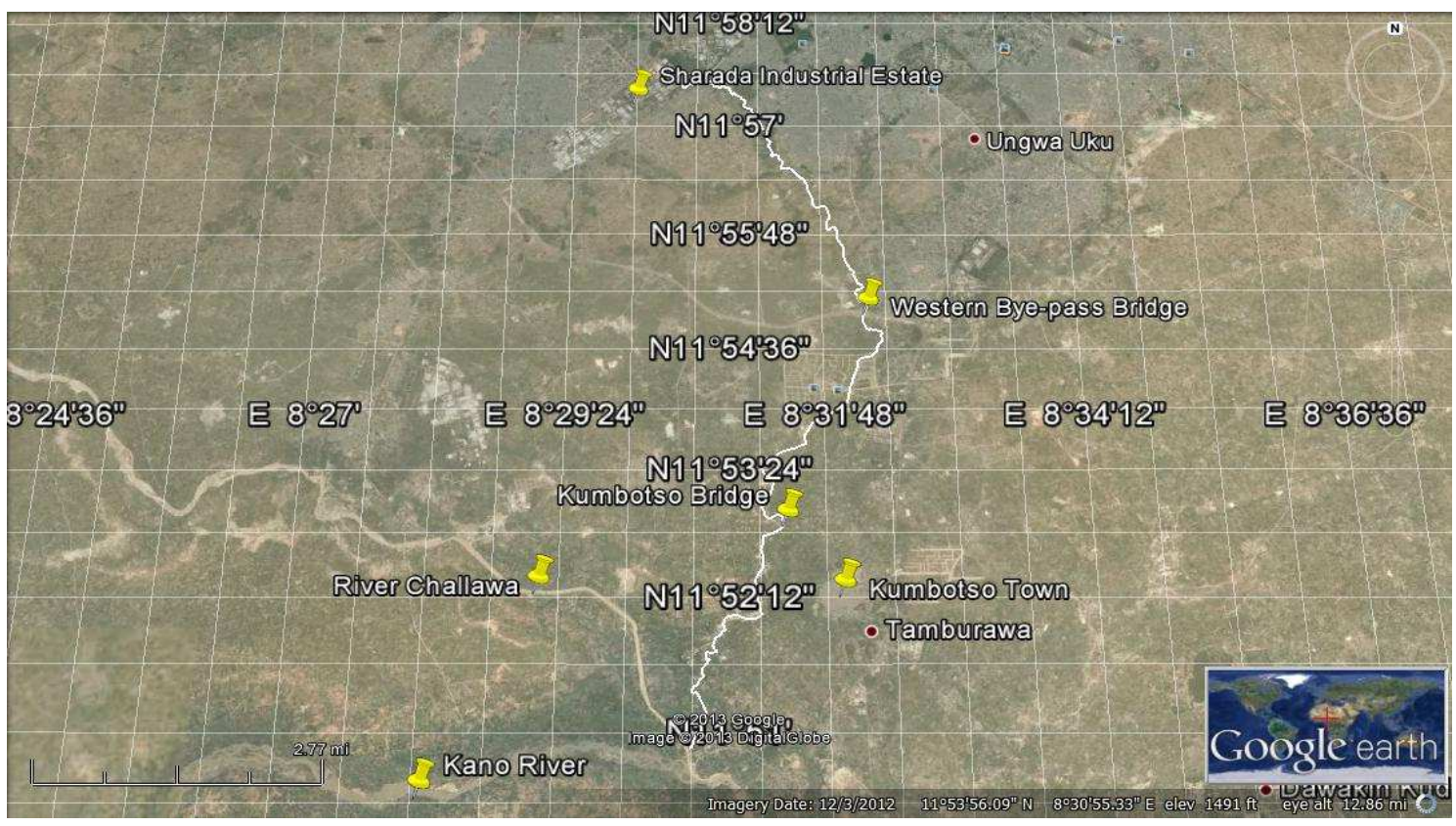

Fig. 1 Google satellite image of the study area outlining the effluent flow path. 


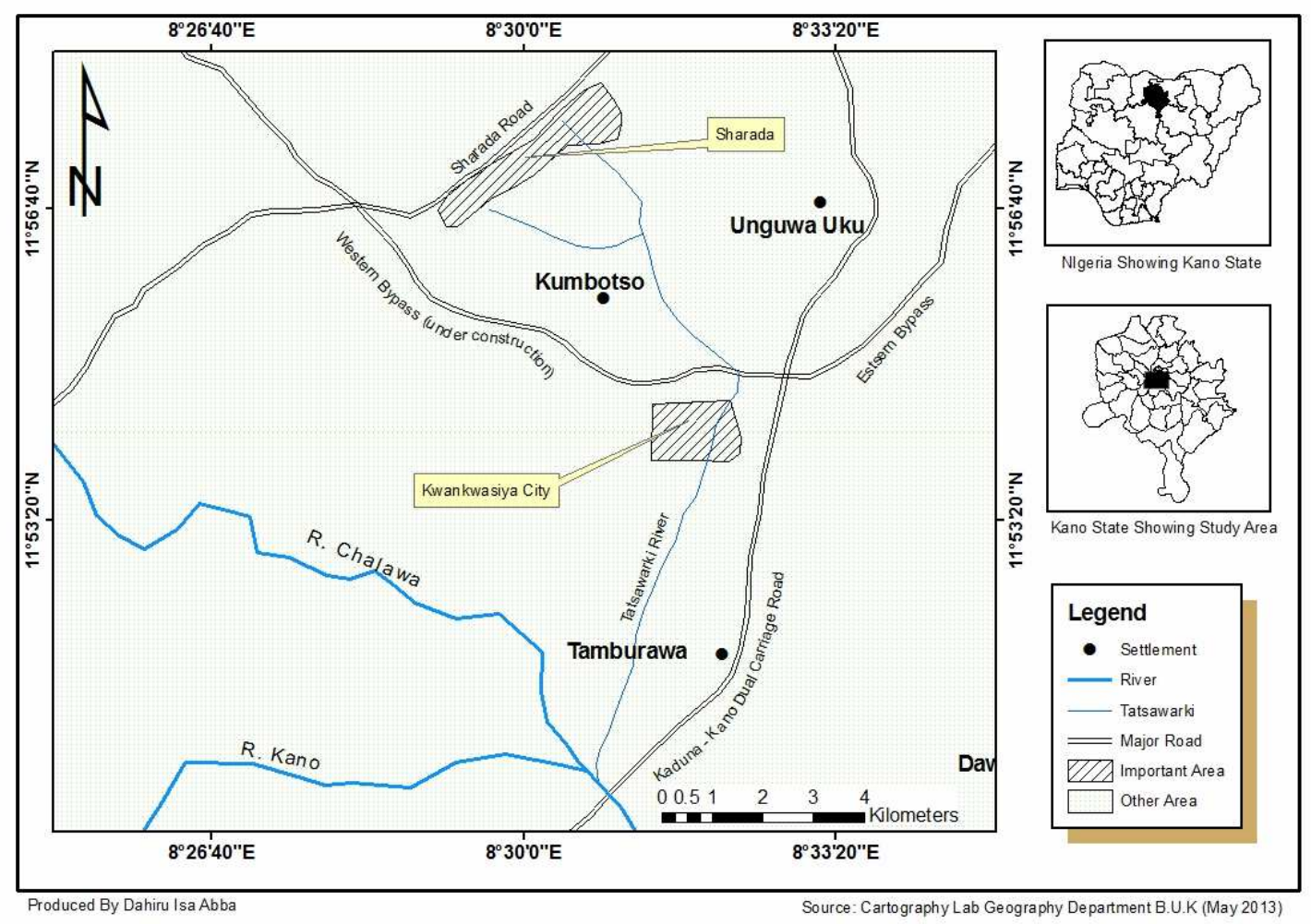

Fig. 2. A sketch map showing the location of Kano State and the study area.

\section{Field Work}

A pre-sampling reconnaissance survey of the study area was conducted to identify prospective soil sampling sites and to put logistics in place prior to soil sampling. The total length of the river has been estimated to be about $18.6 \mathrm{~km}$ covering a longitudinal distance of about $12.3 \mathrm{~km}$. An area of $1.5 \mathrm{~km} \times 0.5$ $\mathrm{km}$ (75 ha) in the downstream portion of the river, precisely from where human settlement started, was selected for sampling. Settlements have overtaken most of the up - and mid- stream portions of the river from the source. The Google Earth Satellite Imagery (Figure 1) and Global Positioning System (GPS) were used to demarcate the extent of the area. A sketch map showing the location of Kano State and the study area is presented in Figure 2. The selection was based on the fact that settlements have overtaken most of the up- and mid-stream portions of the river from the source. The selected sampling site of the river floodplain was divided into three sections namely; upstream, mid-stream and down-stream. Composite surface soil samples were collected from $0-20 \mathrm{~cm}$ using soil auger for analysis. Similarly, composite soil samples were collected outside the floodplain to serve as the absolute control. Irrigation water samples were collected from each section of the river at the point of discharge into the irrigated farms. Similarly, control irrigation water samples were collected from tube wells outside the farms being irrigated with the wastewater (Fig. 3) in each section of the river.

Collection of the water samples was done after the water was pumped for about 30 minutes to make sure that the water was from the aquifer. The water samples were collected in 2-litre plastic containers provided with a cap. The water samples were refrigerated at $\leq 4^{\circ} \mathrm{C}$ before analysis. 
BAJOPAS Volume 9 Number 2 December, 2016

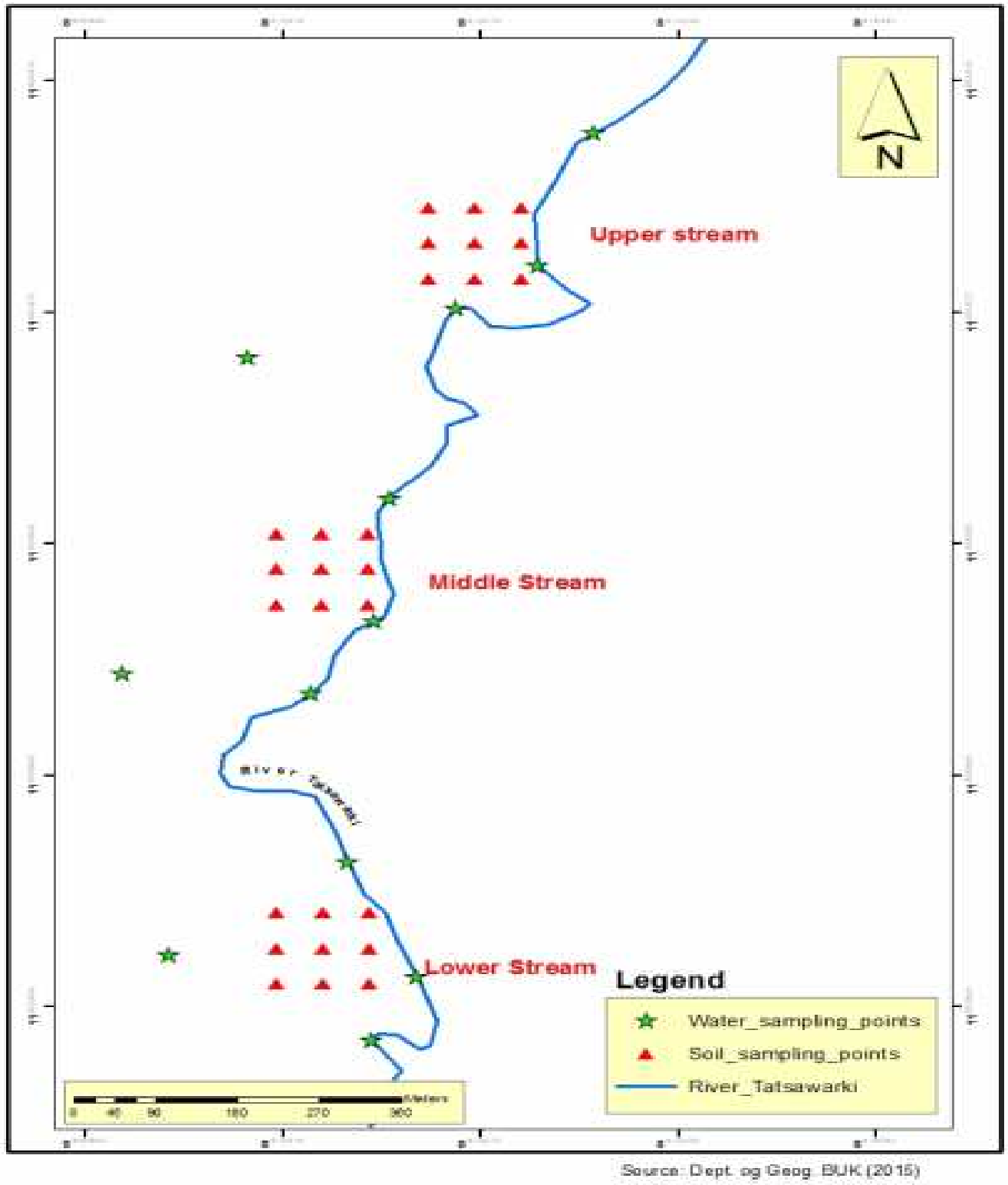

Fig.3. A sketch map showing soils and water sampling points

\section{ANALYTICAL METHODS}

In each soil sample, total concentrations of $\mathrm{Cr}, \mathrm{Pb}, \mathrm{Cd}$, $\mathrm{Cu}$, and $\mathrm{Zn}$ were determined using the procedure described by Sabudak et al; (2007). The concentrations were read on Atomic Absorption Spectrophotometer (AAS) as described by Floyd and Hezekiah (1997). The irrigation water samples were also analyzed for $\mathrm{Cr}, \mathrm{Pb}, \mathrm{Cd}, \mathrm{Cu}$, and $\mathrm{Zn}$ and subsequently digested and the concentrations were also read on AAS (Floyd and Hezekiah, 1997).

\section{RESULTS AND DISCUSSION}

The mean values of the heavy metals concentration in wastewater irrigated Fluvisols in sections of river Tatsewarki in Kano is shown in Figure 4. Copper concentrations varied significantly $(P<0.01)$ among the sections. The distribution did not follow a particular pattern. The concentrations ranged from 30.556 (downstream) to $41.667 \mathrm{mg} / \mathrm{kg}$ (midstream). Mean values from all the sections were higher than the control $(26.667 \mathrm{mg} / \mathrm{kg})$. This clearly indicates that
$\mathrm{Cu}$ was deposited in the farms sampled for analysis particularly at the midstream. This agrees with the finding of Rajinder (2012) and Nguyen et al., (2008) in which they reported higher concentration of $\mathrm{Cu}, \mathrm{Pb}$ and zinc in wastewater irrigated soils as compared with control soils. This finding corroborates the report of Dawaki et al., (2013) that concentrations of heavy metals are higher in soils receiving industrial and domestic sewages in soils of Kano urban agricultural lands. It is also in conformity with the findings of Mashi and Alhassan (2007) that soils in areas receiving industrial wastes recorded highest concentrations of heavy metals in fadama soils in Kano city, Nigeria. Dawaki et al. (2013), however reported very much lower (4.95 - $5.99 \mathrm{mgkg}^{-1}$ ) concentrations of $\mathrm{Cu}$ in similar soils in Kano. This is because, the concentrations of these trace metal in wastewater is seem to be higher than the natural river water. 
Copper is a low mobility metal in near-neutral soils. In more alkaline soils, soluble complexes of $\mathrm{Cu}^{2+}$ can form and increase the total copper solubility. Cadmium varied $(P<0.05)$ among the sections and ranged from 10.26 (upstream) to $18.687 \mathrm{mg} / \mathrm{kg}$ (downstream). It increased downslope (Figure 4). Generally there was no specific pattern of variation in the $\mathrm{Cd}$ concentration between the soils and the control among the sections (Figure 4). This could be attributed to the chemical and physical nature of the soil. It has been reported by Sherene (2010) that addition of phosphatic fertilizers to the soil can lead to an increase in $\mathrm{Cd}$ concentration.

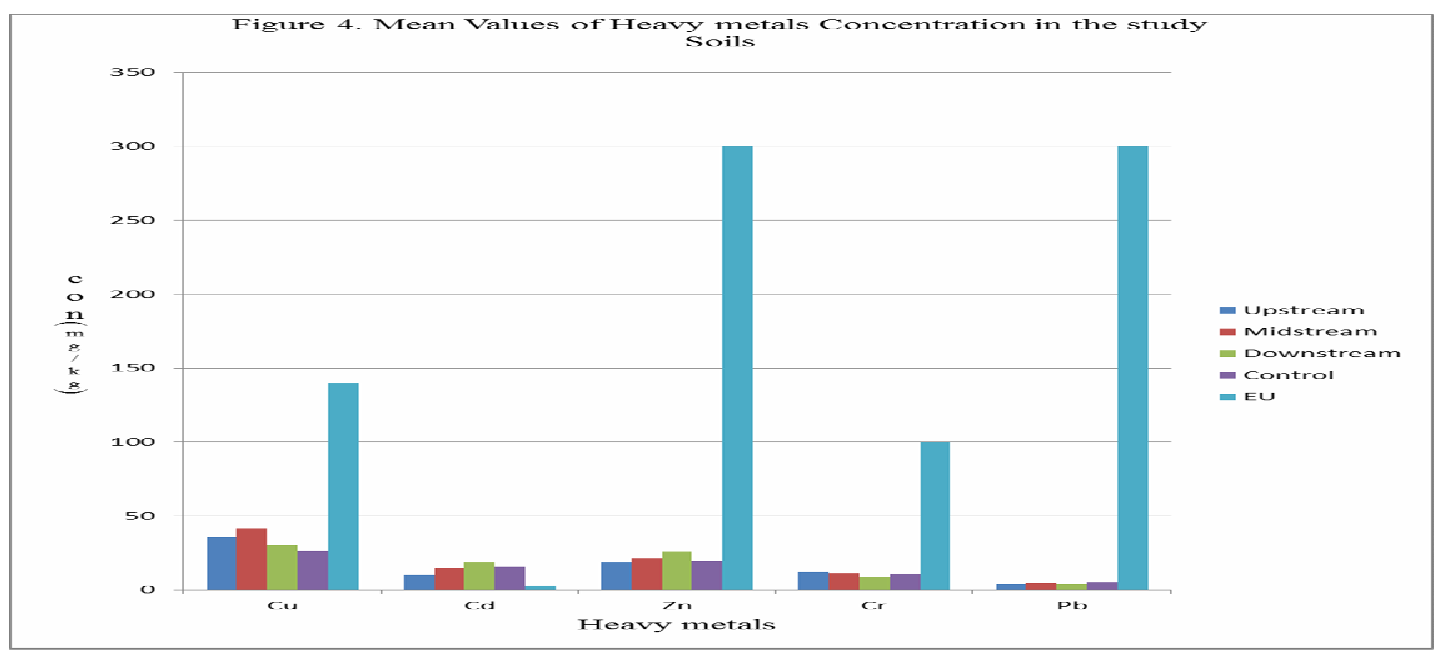

However, the concentration of $\mathrm{Cd}$ was only higher than the control $(15.657 \mathrm{mg} / \mathrm{kg})$ at the downstream section of the river. This is contrary to the findings of Mustapha and Umar (2013) who reported significantly higher amounts of cadmium at all wastewater irrigated areas as compared with the absolute control. The concentration of $\mathrm{Zn}$ showed significant $(P<0.05)$ among the sections (Figure 4) ranging from 18.687 (upstream) to $26.010 \mathrm{mg} / \mathrm{kg}$ (downstream) indicating higher accumulation of $\mathrm{Zn}$ downslope. The mean values at all the sections were higher than the control $(19.687 \mathrm{mg} / \mathrm{kg}$ ) except at the upstream even though the two mean values were statistically at par with each other. Once again this may be attributed to the chemical and physical nature of the soil.

There were no significant differences between $\mathrm{Cr}$ and $\mathrm{Pb}$ concentrations in all the sections. The concentrations of all the heavy metals studied were far less than the EU standard above which crop production may be impaired (Figure 4 ). This means that even though the heavy metals studied generally accumulated in the soils, their concentrations did not reach toxic levels as to negatively affect crop production in the study area.

The mean values of heavy metals in the irrigation water are presented in Figure 5. Among the heavy metals evaluated, only $\mathrm{Zn}$ varied $(\mathrm{P}<0.05)$ across the sections. Zinc concentration was higher at the upstream $(1.06 \mathrm{mg} / \mathrm{l})$. This is expected due to the fact that the upstream is very much closer to the source of the wastewater discharge from the tanning industry than the other sections of the river. The mean value $(1.06 \mathrm{mg} / \mathrm{l})$ was higher than the absolute control $(0.83 \mathrm{mg} / \mathrm{l})$. This indicates that the irrigation water was really contaminated with $\mathrm{Zn}$. Concentration of $\mathrm{Zn}$ was observed to be higher $(0.76 \mathrm{mg} / \mathrm{l})$ at the downstream than at the midstream $(0.58 \mathrm{mg} / \mathrm{l})$. This may not be unconnected with downwards movement of water containing $\mathrm{Zn}$. Generally, the concentration of $\mathrm{Cr}, \mathrm{Cu}, \mathrm{Cd}$ and $\mathrm{Pb}$ increased downslope.

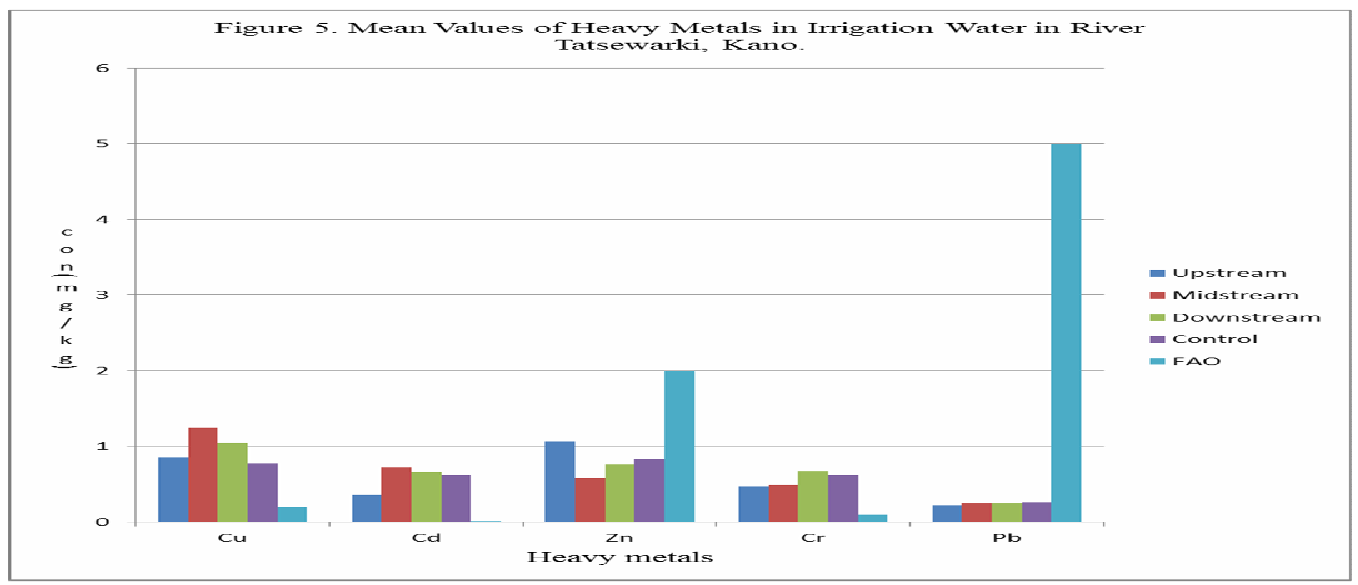


BAJOPAS Volume 9 Number 2 December, 2016

The maximum concentration of heavy metals in irrigation water for it to be safe for use has been reported by FAO (1992) and this maximum limits for the heavy metals are presented in Figure 5 . Concentrations of $\mathrm{Cu}, \mathrm{Cd}$ and $\mathrm{Cr}$ across the sections were higher than the allowable FAO (1992) limits. This implies that the wastewater is not safe for use as irrigation since it can lead to deposition of $\mathrm{Cu}, \mathrm{Cd}$ and $\mathrm{Cr}$ in the soils which negatively affects the soil quality as well as crop production in the study area. However, $\mathrm{Zn}$ and particularly $\mathrm{Pb}$ were within the allowable limits (Figure 5). This means that the irrigation water did not contain toxic concentrations of $\mathrm{Zn}$ and $\mathrm{Pb}$ and therefore considered safe for use as far as these metals are concerned.

The correlation coefficients ( $r$ ) of heavy metals in the soils and in the irrigation water are presented in Table 1. The relationship between $\mathrm{Cr}, \mathrm{Cu}, \mathrm{Cd}$ and $\mathrm{Pb}$ in the irrigation water and in the irrigated soils was positive but non - significant with $r$ values of $0.019,0.151$, 0.190 and 0.202 respectively. This means that irrigation with the wastewater was responsible for the accumulation of $\mathrm{Cr}, \mathrm{Cu}, \mathrm{Cd}$ and $\mathrm{Pb}$ in the irrigated Fluvisols. This finding is in conformity with the reports of Sahu et al., (2007), Nguyen et al., (2008), Kibria, et al., (2012). However, the irrigation water was not responsible for the accumulation of $\mathrm{Zn}$ in the soil ( $r=$ - 0.214). This is probably associated with low concentration and variability of $\mathrm{Zn}$ in the irrigation water as compared with the FAO (1992) maximum limits (Figure 5). It may also be due to other factors as reported by Haghighet and Asadi (2015) that the concentration of heavy metals in soils during irrigation with wastewater depends upon a number of factors such as the element's concentration in wastewater, the period of wastewater irrigation, soil structure, acidity as well as the percentage of soil organic materials.

Table 1. Pearson's correlation of Water Heavy metals with Soil Heavy Metal

\begin{tabular}{llllll}
\hline & $\mathrm{Cr}_{\mathrm{S}}$ & $\mathrm{Cu}_{\mathrm{s}}$ & $\mathrm{Zn}_{\mathrm{s}}$ & $\mathrm{Cds}$ & $\mathrm{Pb}_{\mathrm{S}}$ \\
\hline $\mathrm{Cr}_{\mathrm{w}}$ & 0.019 & 0.359 & 0.272 & 0.491 & -0.354 \\
$\mathrm{Cu}_{\mathrm{w}}$ & -0.230 & 0.151 & -0.133 & -0.144 & -0.208 \\
$\mathrm{Zn}_{\mathrm{w}}$ & 0.445 & -0.079 & -0.214 & 0.034 & 0.315 \\
$\mathrm{Cd}_{\mathrm{w}}$ & -0.077 & 0.296 & 0.061 & 0.190 & 0.104 \\
$\mathrm{~Pb}_{\mathrm{w}}$ & 0.486 & -0.006 & -0.031 & 0.062 & 0.202 \\
\hline
\end{tabular}

NB: $w=$ water $s=$ soil

\section{CONCLUSION}

The study shows that even though the heavy metals studied generally accumulated in the soils, their concentrations did not reach toxic levels. Results also indicated that the irrigation water contained toxic levels of $\mathrm{Cu}, \mathrm{Cd}$ and $\mathrm{Cr}$ and is therefore considered unsafe for use as irrigation water as far as these heavy metals are concerned. However, it did not contain toxic levels of $\mathrm{Zn}$ and $\mathrm{Pb}$. The irrigation water was responsible for the accumulation of all the heavy metals in the soil except $\mathrm{Zn}$.

\section{RECOMMENDATIONS}

It is recommended that periodic appraisal of the soils should be embarked upon so as to monitor the toxicity level of the soil to keep it within the present

\section{REFERENCES}

Aikman, D.I. (1983). Waste Water Re-used from the Standpoint of Irrigated Agriculture, The Health Engineer (Vol.11 NO.1,1983),PP 3541.

Akan, J. C., Moses, E. A., Ogugbuaja, V. O., Abah, J. (2007). Assessment of Tannary Industrial Effluent in Kano Metropolis, Kano State, Nigeria. Department of Chemistry, University of Maiduguri, Faculty of Science, P. M. B. 1069, Nigeria.

Bichi, M. H. and Anyata, B. U. (1999). Industrial Waste Pollution in the Kano Basin. Environmental Management and Health, 10(2): pp. $112-116$.

Contamination and Remediation Directorate (CRD) (2004). Heavy Metals. Aboriginal Affairs and Northern Canada.w.w.w.aandc-aandc gc.ca.

Dawaki, U.M., Dikko, A.U. Noma, S.S. and Aliyu, U. (2013). Heavy Metals and Physicochemical Properties of Soils in Kano Urban Agricultural non-toxic level where applicable. It is also recommended that the wastewater should be remediated to minimize and control the heavy metal contamination through phytoremediation. These measures are expected to enhance increased and sustainable crop production in the area studied.

\section{CONTRIBUTION OF AUTHORS}

The corresponding author is responsible for the scholarly write up of the paper while the co-author was involved in the collection and collation of data from the field.

\section{ACKNOWLEDGEMENT}

The authors acknowledged the contribution of Malam Sule Haruna for assisting in the field work and during the laboratory analysis of the samples collected.

Lands. Nigerian Journal of Basic and Applied Science (September, 2013), 21(3): 239-246.

EU. (2000). The working document on sludge $3^{\text {rd }}$ draft ENV.E/LM.

FAO (1992), Wastewater Treatment and Use in Agriculture by Pescod, M.B. Irrigation and Drainage Paper 47. FAO, Rome. 2 pp.

Floyd, W. B. and S. Hezekiah (1997). Analysis of Coal Ash by Atomic Absorption Spectrophotometric Methods in: Method for Sampling and in Organic Analysis of Coal. Geological Survey Bulletin, 1823 . Golightly D.W and Simon F.O. (Ed) 1-20

FME, (2001) Federal Ministry of Environment Abuja, 2001, Studies for Industrial Effluent Treatment Facilities in Kano City, A Preliminary Report on: Environmental Audit Report, Prepared by Map Industrial Service Limited Nigeria and COMTEN Industries Gmbh, Germany. 
FU, L. J., Stares, R.E. and Stahy, R. G. Jr (1994). Assessing Acute Toxicities of Pre and Post Treatment Industrial Waste waters with Hydra Attenata: A Comparative Study of Acute Toxicity with the Fatheadminnows, Phimephales, Promelas. Environ. Toxicol. Chem, 13:563.

Haghighat, J. P. and Asadi, R. (2015). Effect of Using Waste Water on Soil Chemical Properties Under Drip and Furrow Irrigation, Journal of Biodiversity and Environmental Sciences (JBES) ISSN: 2220 - 6663 (Print) 2222 3045 (Online) Vol. 6, No. 1. P. 102 - 110, 2015 http://www.innspub.net

Jamali. M. K., Kazi, T. G., Arain M. B., Afridi, H. I., Jalbani, N., and Baig J. A. (2009). Heavy Metal Accumulation in Different Varieties of Wheat (Triticum aestivum L.) Grown in Soil Amended with Domestic Sewage Sludge, Journal of Hazardous Materials, 164 \{2-3\}, 1386-1391.

Javaid, A, Ashraf, S. and Bajwa, R. (2000). Effect of Tannery Industrial Effluent on Crops Growth and VAM colonization in Vigna radiate [L] Wilczek and Zea mays L. Pakistant Journal of Biological Science 3.

Kelly J., Thornton I. and Simpson P. R, (1996). Urban Geochemistry: A Study of Influence of an Anthropogenic Activity on Heavy Metal Content of Soils in Traditionally Industrial Areas of Britain, App 1, Geovhem, 11: 363 370.

Kupechella, C.E. and Hyland M. C. (1986). Environmental Science. Allyn and Boron, London, PP. $19-25$

Lentech B.V., (1998 - 2012). Heavy Metals Removal. Email: info @ lenntech, com info @ lenntech. Com.

Kibria, M. G., M. Islam and Alamgir (2012). Influence of Wastewater Irrigation on Heavy Metals Accumulation in Soil and Plant. Department Of Soil Science, University Of Chittagong, Chittagong 4331, Bangladesh School Of Agriculture, Food And Wine, University Of Adelaide, SA 5005, Australia, International Journal of Applied andNatural Sciences (IJANS) Vol.1, Issue 1 Aug 2012 43-54@) IASET.

Mashi, S. A. and Alhassan, M. M. (2007). Effects of Wastewater Discharge on Heavy Metals Pollution in Fadama Soils in Kano City, Nigeria. (PMID: 17458145), Biomedical and Environmental Sciences Journal: BES 2007, 20(1): pp 70-77.

Micó, C., Peris, M., Sánchez, J. and Recatalá, L. (2006). Desertification Research Centre-CIDE (Spanish National Research Council. University of Valencia. Valencian Regional Government). Camí de la Marjal, s/n. 46470 Albal (Valencia). Spain.

Mishra, V. and S. D. Pandy (2005). Immobilization of Heavy Metals in Contaminated Soils using Non Humous Soil and Hydroxy Apetite. Bull. Environ. Biol., 26 197-204 (2005).
Mustapha, H. B. and Umar, F. B. (2013). Heavy Metals in Soils used for Irrigation of Crops along River Tatsawarki in Kano, Nigeria, Department of Civil Engineering, Bayero University, Kano, Nigeria.

Nath, K; S. Sanni and Y. K. Sharma (2005). Chromium in Tannery Industry effluent and its effect on Plants Metabolism and Growth. J. Environ, Biol., 26 197-204 (2005).

Nguyen, M. K., Pham T. Tuan, N. Cong, V. and Ingrid O. (2008). Effects of using wastewater as nutrient sources on soilchemical properties in

peri-urban agricultural systems. College of

Science, VNU, VNU Journal of Science, Earth

Sciences pp. 87-95.

Olofin, E. A. (1987). Some Aspect of the physical geography of the Kano Region and Related Human responses.

Rajinder, S. A. (2012). Impact of Sewage and Industrial Effluents on Soil-Plant Health Department of Soil Science, CCS Haryana Agricultural University, Hisar,India. ISBN 978-953-51-0253-3Hard cover, 274 pages Publisher InTech.

Sabudak, T., Seren, G., Kaykioglu G. and Dincer, A. R. (2007). Determination of Trace Element in Soils and Sunflower, Helianthus annuus. Bull. 16, 1274-1278.

Sahu, R. K., Katiyar S. Tiwari J. and Kisku, G. C. (2007). Assessment of drain water receiving effluent from tanneries and its impact on soil and plants with particular emphasis on bioaccumulation of heavy metals. J. Environ. Biol. 28: 685-690.

Shallari. S., Schwartz C., Hasko, A. and Moral, J. C, (1998). Heavy Metals in Soils and Plants of Serpentine and Industrial Sites of Albani, Sci. Total Environ, 18: 133- 209.Shukry. W. M. (2002). Effect of Industrials Effluent Polluting.

Sherene, T. (2010). Mobility and Transport of Heavy Metals in Polluted Soil Environment. An International Journal Biological Forum: 112121 ISSN: 0975-1130.

Shukry, W. M. (2001). Effect of industrial effluents polluting the river Nile on growth, metabolism and productivity of Triticum aestivum and Vcia faba plants. Pakistan Journal of Biological Sciences 4: 1153 1159. 